\title{
Annual and seasonal variation in the food supply harvestable by knot Calidris canutus staging in the Wadden Sea in late summer
}

\author{
Leo Zwarts ${ }^{1}$, Anne-Marie Blomert ${ }^{2}$, Jan H. Wanink ${ }^{1,2}$ \\ ${ }^{1}$ Rijkswaterstaat Flevoland, PO Box 600, 8200 AP Lelystad, The Netherlands \\ ${ }^{2}$ Zoological Laboratory, University of Groningen, PO Box 14,9750 AA Haren, The Netherlands
}

\begin{abstract}
The biomass of the macrobenthic animals living in intertidal flats of the Wadden Sea varies annually and seasonally. However, the variation in prey biomass harvestable by wading birds such as knot Calidris canutus, which feed mainly on the middle range of their prey size classes, is even larger. The majority of first-year Cerastoderma edule, Mya arenaria or Mytilus edulis are too small to be profitable as prey for knot. Yet, by the end of the subsequent growing season, these same prey are too large to be ingested and/or live at a depth that puts them out of reach of the birds' bills. Macoma balthica is a major prey for knot, because (1) its annual spatfall is less erratic than in the other bivalve species, and (2) it grows more slowly, and each cohort is therefore available as food for knot for at least 3 yr. Knot feed in flocks which roam over the feeding area, but they are more often observed in food-rich than in food-poor areas. A similar relationship between bird and food densities was found in one locality, when the annual numbers of knot were compared with the yearly variation in food supply. Since the numbers of knot in the whole area were the same over many years, the birds were apparently able to find other feeding areas when the local food supply was low, i.e. the food supply harvestable by knot (prey not too small, not too large and not too deep) was less than about $4 \mathrm{~g}$ ash-free dry weight $\mathrm{m}^{-2}$. Knot arrive in the study area at the end of July and leave after only a few weeks en route to Africa. They depart before a serious decline in the harvestable prey biomass takes place, which results from a decrease in the body condition of individual prey and an increase in the fraction of the prey which burrows out of the reach of the knot's bill.
\end{abstract}

\section{INTRODUCTION}

In late summer, when waders arrive in the Wadden Sea from their arctic breeding areas, they face a fluctuating food supply which implies adjustment of diet and aggravates the problem of how to locate reliable food resources. This unpredictability is caused by annual variation in the densities of the approximately 20 species of prey living in the intertidal flats (Beukema et al. 1978, Beukema 1979, 1982, 1989). Indeed, the variation in amount of food harvestable by the various wader species may be even greater than appears from a consideration of the annual total biomass of the prey. Generally, waders only consume part of the prey because they usually ignore the smaller size classes, while the larger prey are too large to be swallowed and/or live too deep in the sediments to be caught (Zwarts \& Wanink 1984, Piersma 1987). For instance, knot Calidris canutus feeding on Macoma balthica ignore prey less than $9 \mathrm{~mm}$ long and cannot swallow prey longer than $16 \mathrm{~mm}$, while prey are unaccessible when buried more than 2 to $3 \mathrm{~cm}$ below the surface. The remaining fraction is defined as harvestable prey (Fig. 1; Zwarts \& Blomert 1992 [companion paper]).

Furthermore, food density is highly variable spatially, and there are many areas where prey are so sparse that the birds are not actually able to feed on them. Just like prey that are buried too deep to reach, such low-density areas cannot be regarded as part of the bird's food supply. Because of these reasons, regarding the entire prey biomass as the food for a wader species will usually give highly inflated results.

After arrival from their Siberian breeding areas, knot of the subspecies concerned, Calidris canutus canutus, remain some weeks in the Wadden Sea to prepare for a long-distance flight which takes them to their tropical wintering grounds (Piersma et al. 1990, 1991). The present report describes, on the basis of a decade of sampling, annual and seasonal variations in the harvestable food supply for knot. The data were used to 


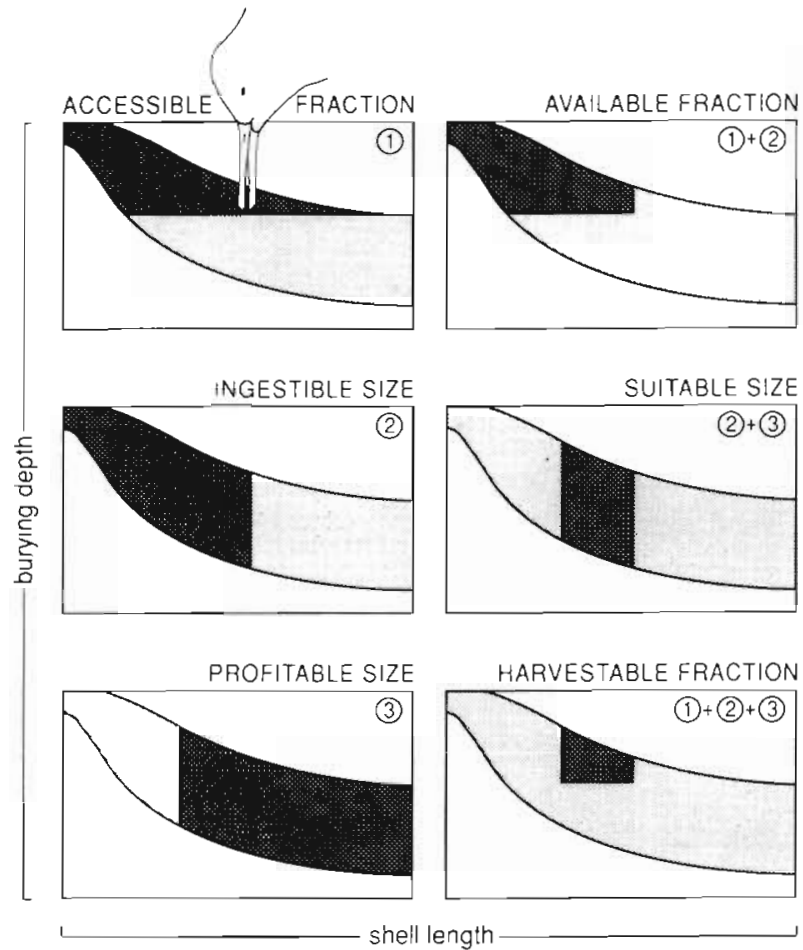

Fig. 1 Terms used in this paper to define different fractions of benthic prey of knot Calidris canutus. Shaded areas: depth below the surface where the prey occur Dark shading: prey which are (1) accessible, (2) ingestible or (3) profitable for knot. Available prey are accessible and ingestible. Prey of suitable size are ingestible and profitable. Harvestable prey are accessible, ingestible and profitable

investigate: (1) standing crop level of the harvestable food supply below which the birds cease to exploit an area (prey harvestable by knot are, by definition, available as well as profitable - Fig. 1; Zwarts \& Blomert 1992); (2) whether this threshold, or minimum acceptance level, is set by the relation between the harvestable food supply and the rate at which food can be taken; (3) whether knot remain in the Wadden Sea until their harvestable food supply reaches this level of minimum acceptance and so becomes too low, or whether instead they depart regardless of food supply.

\section{METHODS}

The study was done between 1976 and 1986 in the eastern part of the Dutch Wadden Sea on intertidal mudflats along the Frisian coast $\left(53^{\circ} 25^{\prime} N, 6^{\circ} 04^{\prime} E_{\text {; Fig. }}\right.$ 2). The remains of brushwood groynes made several decades before to enhance sedimentation were used as markers bordering 53 sites which varied in size between 6 and 26 ha. The total surface area of these 53 sites was 396 ha (Fig. 2). The elevation of this area varied between $50 \mathrm{~cm}$ above and $30 \mathrm{~cm}$ below mean sea level, which corresponds to average emersion times

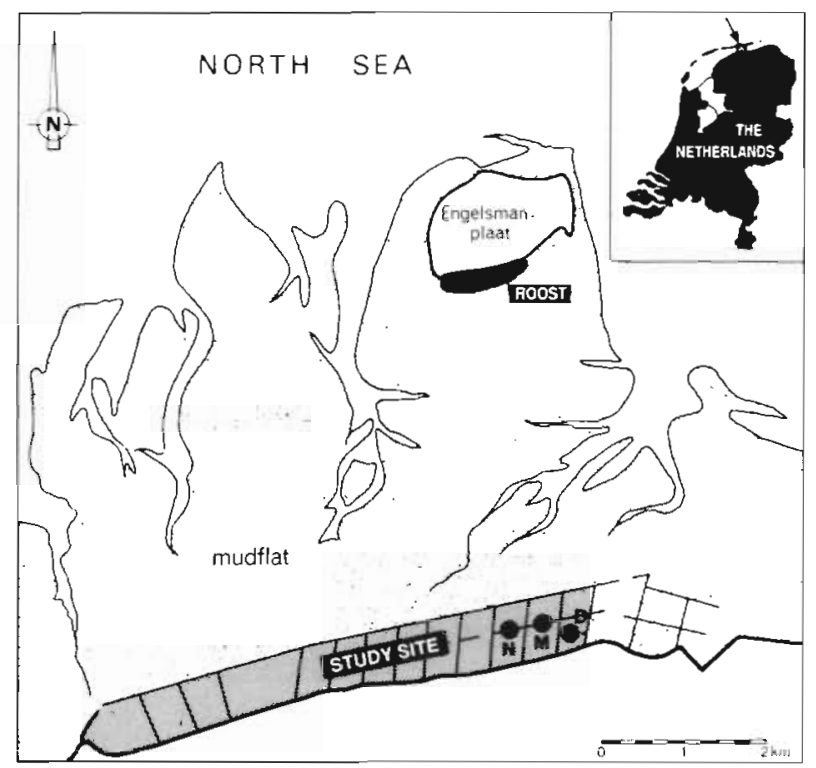

Fig. 2. Study area in the eastern part of the Dutch Wadden Sea. The area shaded grey was intersected with brushwood groynes. Detailed observations of knot and their food supply were made on 146 plots of 0.1 ha (Sites $N$ and $M$ ). Burying depth of bivalves was measured at Site $D$, and sometimes at Sites $N$ and $M$

of $62 \%$ and $39 \%$ of the tidal cycle (12 h 25 min), respectively. The substrate was muddy, with the clay content $(<2 \mu \mathrm{m}$ ) being 2 to $20 \%$ (Zwarts 1988). Waders were counted in the study area at low tide from the top of the sea wall ( $9 \mathrm{~m}$ high), usually twice a month, over the period 1977 to 1985. All the knot from the study area roosted on the island Engelsmanplaat, along with birds feeding on tidal flats further offshore. Roosting birds were counted by local wardens several times a week during summer.

Two sites ( $N$ and $M$ in Fig. 2) were selected for more detailed observations: 146 plots of 0.1 ha were pegged out and 2 towers built to observe the waders. The feeding densities were determined by counting waders in the plots every 30 min over the entire low water period. Sites $N$ and $M$ were situated just below mean sea level; the clay content of the substrate was 4 to $5 \%$.

Core samples of the macrozoobenthos $\left(1 / 56 \mathrm{~m}^{2}\right)$ were sieved through a $1 \mathrm{~mm}$ screen. A detailed description of the procedures used to determine the ash-free dry weight (AFDW) is given elsewhere (Zwarts 1991). Samples were taken at equally spaced intervals (200 m) along 27 transects over the entire study area in August during 4 yr (1977 to 1980). Also, 73 or 292 cores were collected from Site $N$ almost every month over the period 1980 to 1986 .

During the same $7 \mathrm{yr}$, burying depth of Macoma balthica was determined once or twice a month at nearby Site $D$, and sometimes on Site $N$ or $M$; the techniques used are described in Zwarts \& Wanink 
(1989). To maintain a sample size of at least 100 depth measurements for each of the fortnightly periods, the calculations related to all specimens of 10 to $23 \mathrm{~mm}$ in length, although knot only selected the size classes smaller than $16 \mathrm{~mm}$ (Zwarts \& Blomert 1992). Since there was no relationship between size and burying depth for animals larger than $10 \mathrm{~mm}$, the inclusion of larger individuals did not influence the trends shown.

Growth of the bivalves was estimated from their length frequency distributions in the monthly samples, using the Bhattacharya method for separating cohorts (MPA module of the Compleat ELEFAN software package, version 1.0; Gayanilo et al. 1988)

\section{RESULTS}

\section{Numbers of knot}

The majority of knot arrive in the study area around 1 August, and most have left the area by $3 \mathrm{wk}$ later (Fig. 3). The timing of departure can be ascertained because, when knot start a long distance flight, they become noisy and nervous and then disappear in a southwesterly direction (Piersma et al. 1990). From this, we know that the knot leave the area by mid-August (Fig. 3B), which coincides well with the decrease in numbers recorded on the feeding and roosting areas (Fig. 3A).

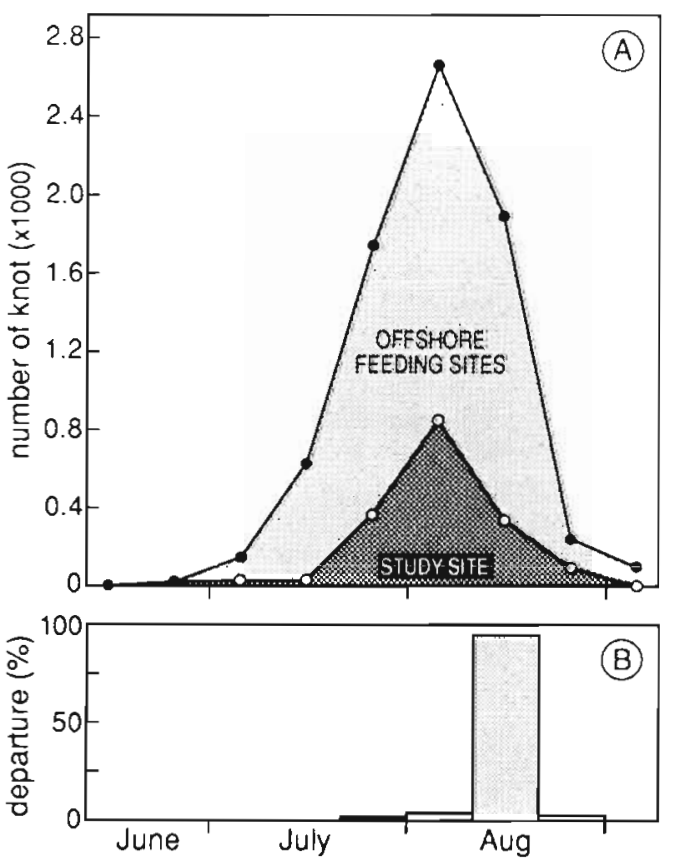

Fig. 3. Calidris canutus. (A) Average number of knot present on the roost at high tide in the period 1976 to 1990 (190 counts done by the wardens; compiled by Lenze Hofstee) and in the study area at low tide (65 counts from 1977 to 1985).

(B) Timing of departure from the eastern part of the Dutch Wadden Sea between 1964 and 1988; n = 3465 birds

\section{Annual food supply}

The main prey for knot in the Wadden Sea are bivalves and snails (Boere \& Smit 1981, Nehls 1992, Zwarts \& Blomert 1992, Piersma pers. comm.). In contrast to Macoma balthica and Mya arenaria, annual variation in the total biomass of Mytilus edulis and Cerastoderma edule in Site N was very large (Table 1). Though the fluctuations were damped when these species were taken together, the lowest total biomass was still only half of the highest (Table 1). The average biomass of the 5 bivalve species taken together at Site $N$ was $73 \mathrm{~g} \mathrm{AFDW} \mathrm{m}^{-2}$, which is high compared with the average of 13 to $23 \mathrm{~g} \mathrm{AFDW} \mathrm{m}^{-2}$ over the entire Dutch Wadden Sea (Beukema 1976, 1978, 1989). The total biomass of $M$. edulis was low, but all the other species, especially Scrobicularia plana, reached an extremely high biomass. The biomass of these species did not deviate much, however, from the values found in other, similarly sheltered areas with mixed substrate, situated at or just above mean sea level (Beukema 1976, Zwarts 1988).

Table 1. Annual variation in the biomass of prey species of knot Calidris canutus (g AFDW $\mathrm{m}^{-2}$ ) at Site $\mathrm{N}$ in August of 1977 to 1986. Average, lowest and highest biomass are given. RSD: relative standard deviation (SD as percentage of the mean)

\begin{tabular}{|lrrr|}
\hline Species & $\begin{array}{c}\text { Average } \\
(\mathrm{g})\end{array}$ & \multicolumn{1}{c|}{$\begin{array}{c}\text { Range } \\
(\mathrm{g})\end{array}$} & \multicolumn{1}{c|}{$\begin{array}{c}\mathrm{RSD} \\
(\%)\end{array}$} \\
\hline Macoma balthica & 17.22 & $7.4-34.5$ & 46.6 \\
Cerastoderma edule & 20.66 & $0-62.3$ & 107.2 \\
Mya arenaria & 13.20 & $7.0-23.7$ & 38.6 \\
Scrobicularia plana & 20.23 & $8.1-46.3$ & 86.5 \\
Mytilus edulis & 1.45 & $0-7.9$ & 186.6 \\
Total & 73.26 & $52.8-111.0$ & 26.6 \\
\hline
\end{tabular}

Table 2. Annual variation in the biomass within the range of size classes harvestable by knot Calidris canutus (g AFDW $\mathrm{m}^{-2}$; without depth restriction) at Site $\mathrm{N}$ in August of 1977 to 1986. Range of harvestable size classes are taken from Zwarts \& Blomert (1992). Average, lowest and highest biomass harvestable by knot are given. RSD: relative standard deviation ( $S D$ as percentage of the mean)

\begin{tabular}{|lcrrr|}
\hline Species & $\begin{array}{c}\text { Size } \\
\text { range } \\
(\mathrm{mm})\end{array}$ & $\begin{array}{c}\text { Average } \\
(\mathrm{g})\end{array}$ & $\begin{array}{c}\text { Range } \\
(\mathrm{g})\end{array}$ & \multicolumn{1}{c|}{$\begin{array}{c}\mathrm{RSD} \\
(\%)\end{array}$} \\
\hline Macoma balthica & $6-16$ & 7.81 & $3.9-14.9$ & 44.0 \\
Cerastoderma edule & $5-12$ & 1.25 & $0-6.6$ & 155.7 \\
Mya arenaria & $7-17$ & 0.33 & $0-1.3$ & 153.4 \\
Scrobicularia plana & $7-14$ & 0.14 & $0-1.4$ & 300.0 \\
Mytilus edulis & $5-20$ & 0.33 & $0-2.6$ & 237.9 \\
Total & & 9.86 & $3.9-17.7$ & 45.9 \\
& & & & \\
\hline
\end{tabular}


Knot do not swallow large prey and they ignore the small size classes (Zwarts \& Blomert 1992). Table 2 gives the range of size classes harvestable by knot and the corresponding biomass for these size classes at Site N. A comparison of Tables 1 \& 2 reveals that only a small fraction of the total biomass fell within the range of size classes harvestable by knot. The exception was Macoma balthica for which, on average, $44 \%$ of the total biomass may be considered as harvestable by knot. Moreover, of all the potential prey species, the annual variation in harvestable biomass is least in $M$. balthica.

The large annual variation in total food supply was caused by the erratic occurrence of summer recruitment and winter mortality (Beukema et al. 1978, Beukema 1979, 1982, Beukema \& Essink 1986, Desprez et al. 1991, Ducrotoy et al. 1991، Essink et al. 1991, Jones \& Park 1991, Obert \& Michaelis 1991). There were also large differences among species in annual growth rate and mortality (Fig. 4). Cerastoderma edule grew rapidly but the major-

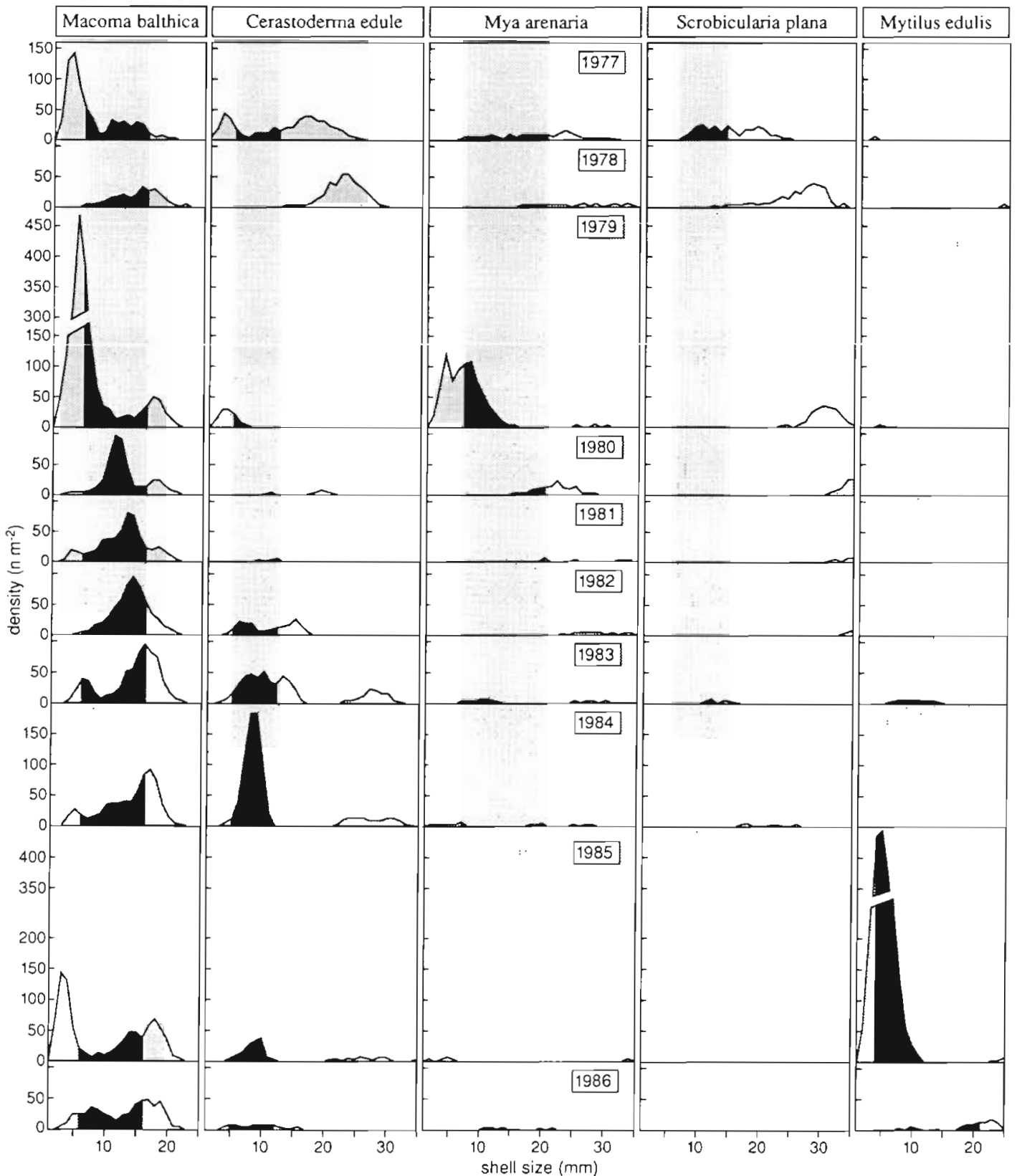

Fig. 4. Density (no. $\mathrm{m}^{-2}$ ) of 5 hivalve species at Site $\mathrm{N}$ in August during 10 yr (1977 to 1986). The size classes harvestable by knot Calidris canutus (i.e. not too small to be unprofitable or too large to be ingestible or accessible) are indicated by vertical grey bars (from Zwarts \& Blomert 1992). Data for 1977 are not directly comparable with the following years since the samples were taken from a larger area 
ity died within 2 or $3 \mathrm{yr}$. There was recruitment in this species during 7 of the 10 years, but the only substantial cohort originated in 1984. No spatfall of any significance occurred in Scrobicularia plana during the 10 years after 1976, when a strong year class was recruited (see also Essink et al. 1991). Many of these animals were still alive in 1983 and 1984. In Mya arenaria as well, there was heavy spatfall during only 1 of the 10 years, viz. 1979. Recruitment was variable in Macoma balthica, but the variation was not as large as in the other species: in 6 of the 10 years there was recruitment, with a considerable spatfall occurring in 3 of them.

\section{Food of knot}

After the first growing season, Mya arenaria reached a size of 5 to $10 \mathrm{~mm}$ and grew to about $25 \mathrm{~mm}$ by the end of their second summer (Figs. $4 \& 5$ ). This means that the majority of the first-year animals were ignored by knot since they were too small and therefore unpro-

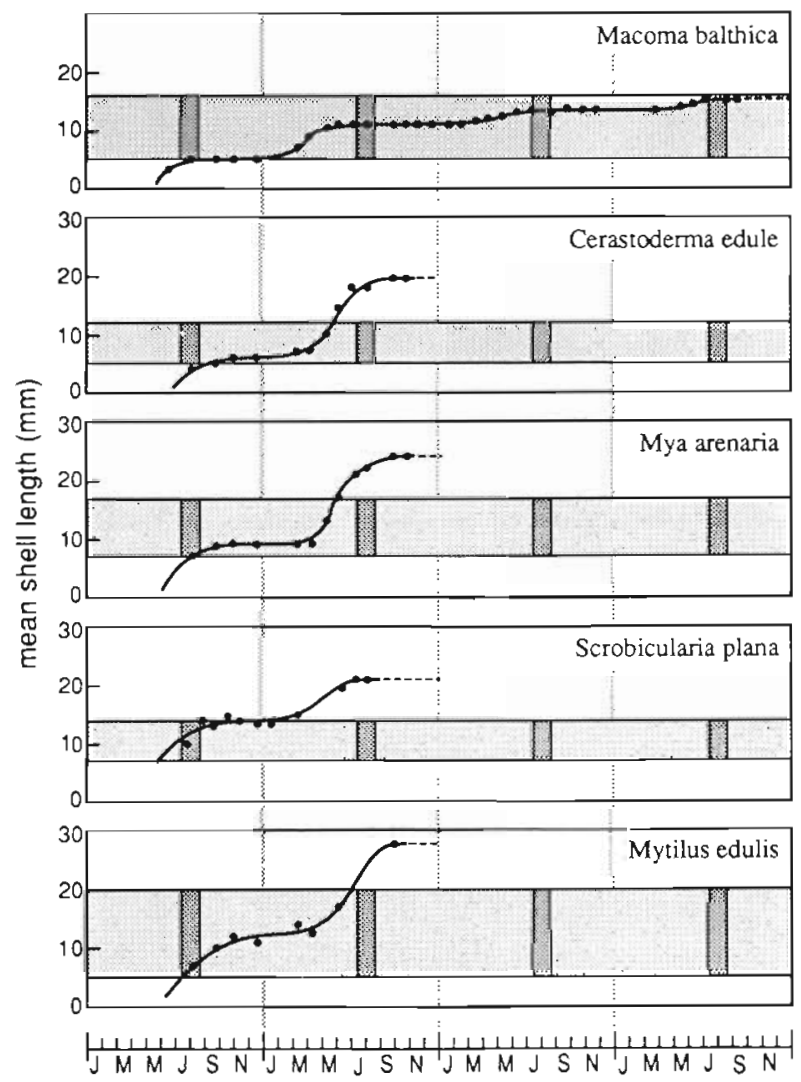

Fig. 5. Growth of 5 bivalve species at Site $\mathrm{N}$ after spatfall in summer 1979 (1983 for Scrobicularia plana). The size classes vulnerable to predation by knot (see Table 2) are indicated (horizontal grey field), as well as the period during which knot were present (vertical grey bars). Average sizes were calculated from the length frequency distributions in the monthly samples (see 'Methods') fitable, while by the end of the next growing season they had become too large to be swallowed. For the same reason, only the largest Cerastoderma edule and Mytilus edulis in their first year and the most slowly growing individuals in their second year were potential prey for knot. However, knot were able to feed on Macoma balthica over a much longer period, as it took a cohort of this species 4 years to pass through the 'window of predation' (Figs. 4 \& 5).

The potential importance of Macoma balthica as prey is also clear from Fig. 6, which shows the annual variation in biomass of the size classes harvestable by knot. The other prey contributed, on average, only $21 \%$ of this biomass (Table 2). Scrobicularia plana, though one of the 2 most important prey in terms of total biomass (Table 1), was of interest for knot only in the year before the observations began, and not at all over the next $10 \mathrm{yr}$. The contribution of the 1979 year class of $M$. balthica to the biomass harvestable by knot is evident: the harvestable food supply was highest after 4 growing seasons and decreased thereafter, because an increasing proportion had passed the critical size threshold of $16 \mathrm{~mm}$.

On some occasions, Macoma balthica was the only prey species harvestable by knot, for example in late summer of 1981 and 1983. Though Cerastoderma edule were available in 1983, knot ignored them, perhaps due to the thick shell (Zwarts \& Blomert 1992). M. balthica must therefore have been the staple food for knot that passed through the study area in late summer, unless the mud snail Peringia ulvae was taken as an alternative. This species usually occurred at densities of 40000 to $50000 \mathrm{~m}^{-2}$, though the summer of 1979 was an exception,

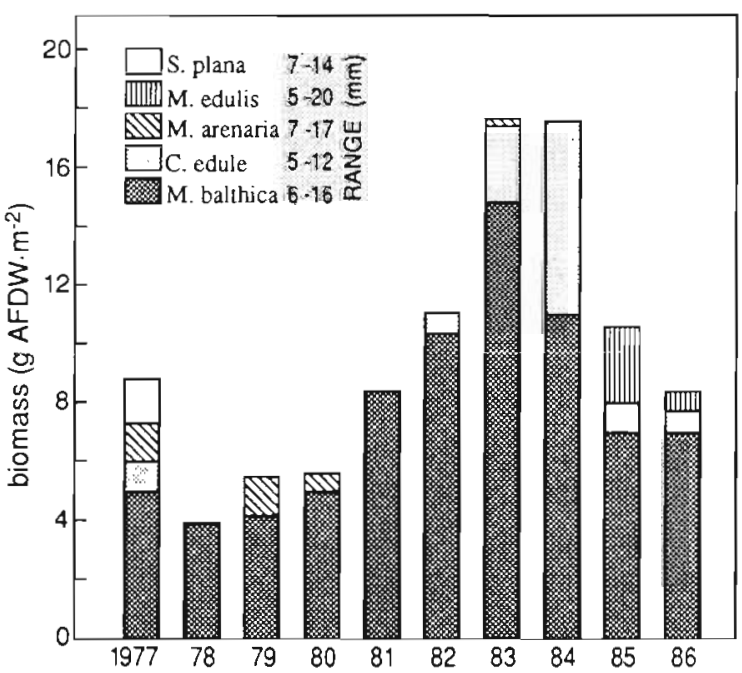

Fig. 6. Biomass (g AFDW $\mathrm{m}^{-2}$ ) of 5 bivalve species at Site $\mathrm{N}$ in August from 1977 to 1986 . A selection has been made for the range of size classes harvestable by knot Calidris canutus (see Table 2). No correction has been made for depth distribution of the prey 
when only low densities of $1000 \mathrm{~m}^{-2}$ occurred (Zwarts 1988). However, direct observations and faecal analysis showed that $P$. ulvae were not taken in 1979, 1981, 1983 or 1985, even though they were abundant in 3 of the 4 years. In fact, the majority of $P$. ulvae in the study area were too small $(<2 \mathrm{~mm})$ to be profitable food items for knot (Zwarts \& Blomert 1992). The distribution pattern of knot over the feeding area was another indication that knot did not feed on $P$. ulvae. This prey was superabundant at the sites situated above mean sea level and in areas where the clay content of the substrate was above $10 \%$ (Zwarts 1988). However, knot ignored these areas and were usually found on sites below mean sea level where the clay content of the substrate was less than $3 \%$. This resulted in a negative relationship between the density of knot and that of $P$, ulvae. Considering all this information together, the conclusion is that $M$. balthica was the main, and sometimes the only, prey for knot in the study area. For that reason, local and seasonal variations only in $M$. balthica are described below.
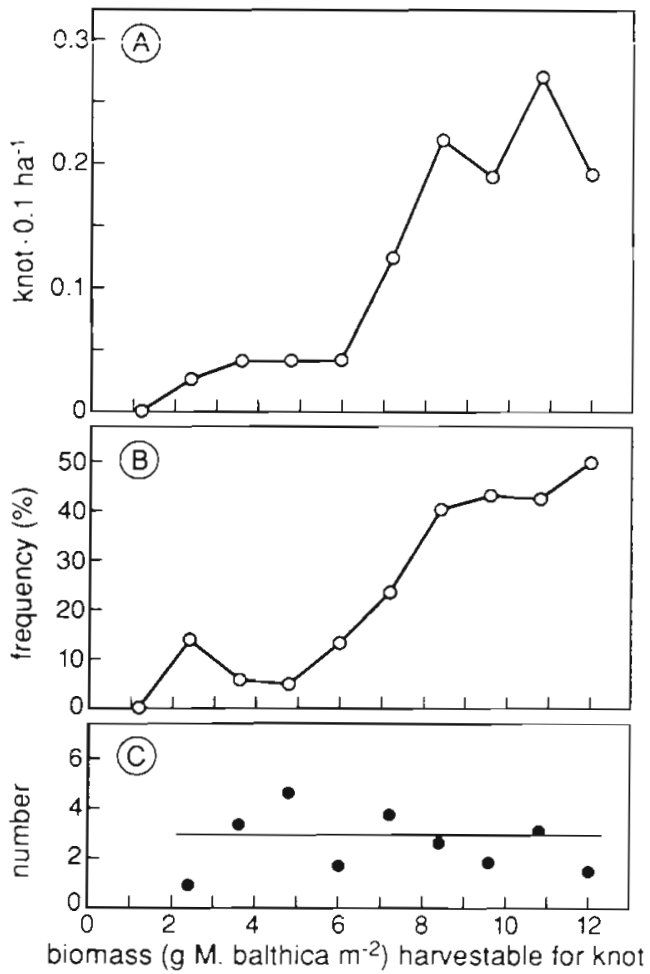

Fig. 7 Calidris canutus. Aggregative response of knot in relation to spatial variations in the harvestable food supply ( $g$ AFDW $\mathrm{m}^{-2}$ of Macoma balthica 6 to $16 \mathrm{~mm}$ long living in the upper $2 \mathrm{~cm}$ of the substrate; $60 \%$ of the prey were found in the upper $2 \mathrm{~cm}$ ). The data refer to 146 plots of 0.1 ha at Sites $N$ and $M$ from July to September $1981 ; 1095$ samples at $1 / 56 \mathrm{~m}^{2}$ were taken. (A) Average feeding density, calculated over 67 counts made during 7 low-water periods. (B) Frequency of occurrence (percent of low-water periods during which one or more knot were counted). (C) Average number (number of knot seen in a plot when the number of knot was $\geq 1$ )

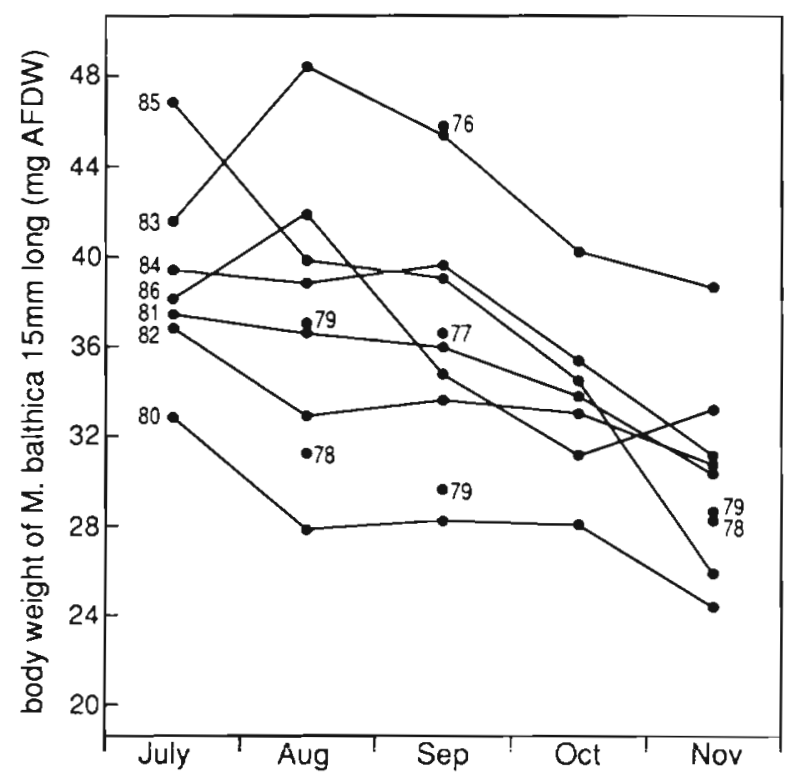

Fig. 8. Macoma balthica. Body weight (mg AFDW) of individuals $15 \mathrm{~mm}$ long in the study area during late summer and autumn between 1976 and 1986 (based on Zwarts 1991)

\section{Knot return to sites with a high food supply}

The distribution of knot over the feeding area in relation to the density of their harvestable prey was investigated in late summer 1981. The biomass harvestable by knot varied between 2 and $12 \mathrm{~g} \mathrm{AFDW} \mathrm{m}^{-2}$, and the density of knot increased with food supply over this range (Fig. $7 \mathrm{~A}$ ). Such an aggregative response of predators to spatial variations in prey density can be divided into 2 components: the frequency with which the predators occur and the numbers present on any one occasion. In the case of knot (Fig. 7A), the response was not determined by the numbers of birds present at any one time (Fig, $7 \mathrm{C}$ ), but by the frequency with which they occurred in a plot (Fig. 7B).

This was perhaps to be expected, in view of the observation that knot almost always fed in flocks which were always on the move, even on a scale of $<1 \mathrm{~h}$. They moved readily from one locality to another, probably continuously seeking the most rewarding place (GossCustard 1970, Gerritsen et al. 1983). Knot found the best parts of the feeding area by ignoring, or rapidly traversing, marginal areas (Fig. 7B).

\section{Annual food supply and number of knot}

Macoma balthica did not grow between July and November (Fig. 5) and there was no decrease in densities during these months (Zwarts \& Wanink unpubl.). Nonetheless, the food supply harvestable by knot decreased over the period, for 2 reasons. Firstly, 
the biomass of individual prey, or their condition, decreased by 20 to $30 \%$, although this seasonal trend was small in comparison with annual differences (Fig. 8). Secondly, the proportion of $M$. balthica living in the upper $2 \mathrm{~cm}$ of the substrate, and thus within reach of the bill of knot, decreased during the season (Fig. 9). However, there were also considerable differences among years in depth distribution. In 1984, the majority of prey remained within reach of the bill until October, whereas in 1980 and 1986, M. balthica were beyond reach of the bill from August onwards. The accessible fraction therefore decreased gradually over the course of the season, but 1985 was an exception since $M$. balthica lived at a greater depth in August than in September

Fig. 10 shows the decrease in biomass of Macoma balthica harvestable by knot. This figure combines the measurements of prey density (Fig. 4), prey weight (Fig. 8) and the proportion of prey actually within reach of knot (Fig. 9). Fig. 10 also shows when knot occurred in the study site in the different years. It is evident that
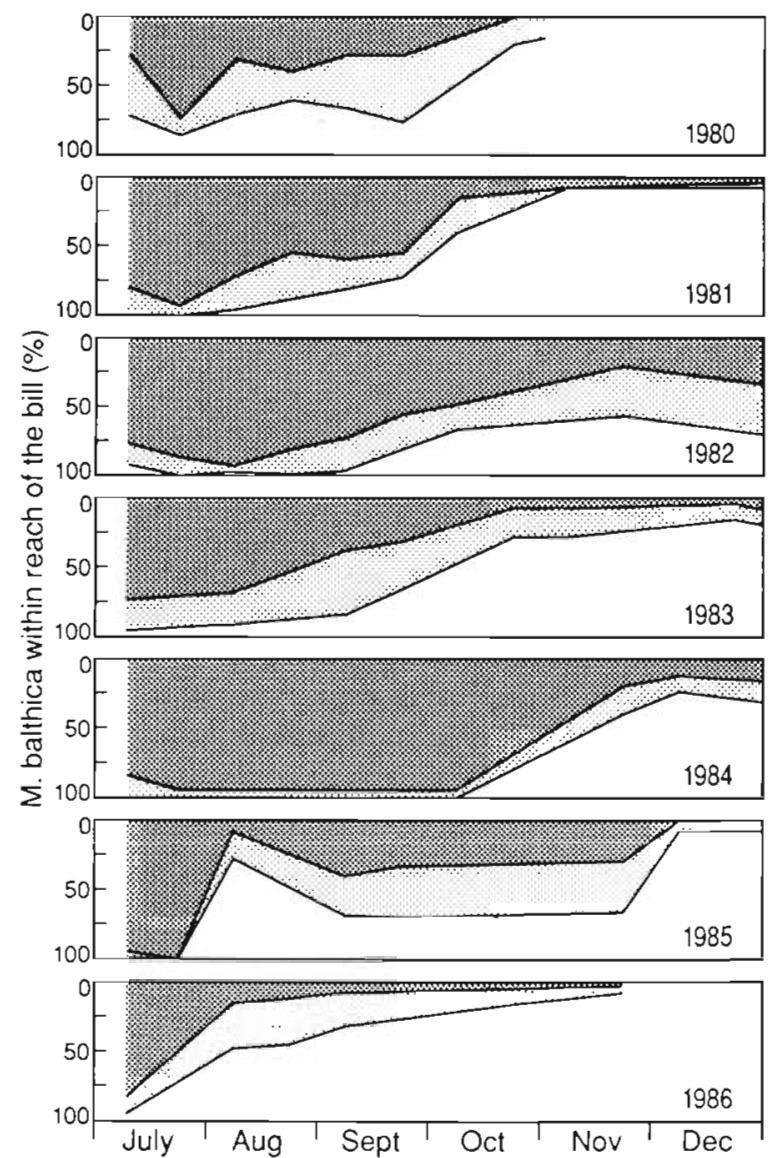

Fig. 9. Proportion of Macoma balthica accessible to knot Calidris canutus, i.e. prey living in the upper $2 \mathrm{~cm}$ (dark shading) and upper $3 \mathrm{~cm}$ (dark + light shading) of the substrate; measurements taken in the study area from 1980 to 1986 (based on Zwarts \& Wanink 1989) the numbers of knot feeding were closely related to the annual variation in biomass of $M$. balthica harvestable by knot.

\section{DISCUSSION}

\section{Response of knot to spatial variation in their harvestable food supply}

Knot most often visited plots with abundant Macoma balthica (Fig. 7B), presumably because their rate of food intake was highest in these areas. The relation between prey density and the rate at which probing knot encounter $M$. balthica (Fig. 11A) can be used to

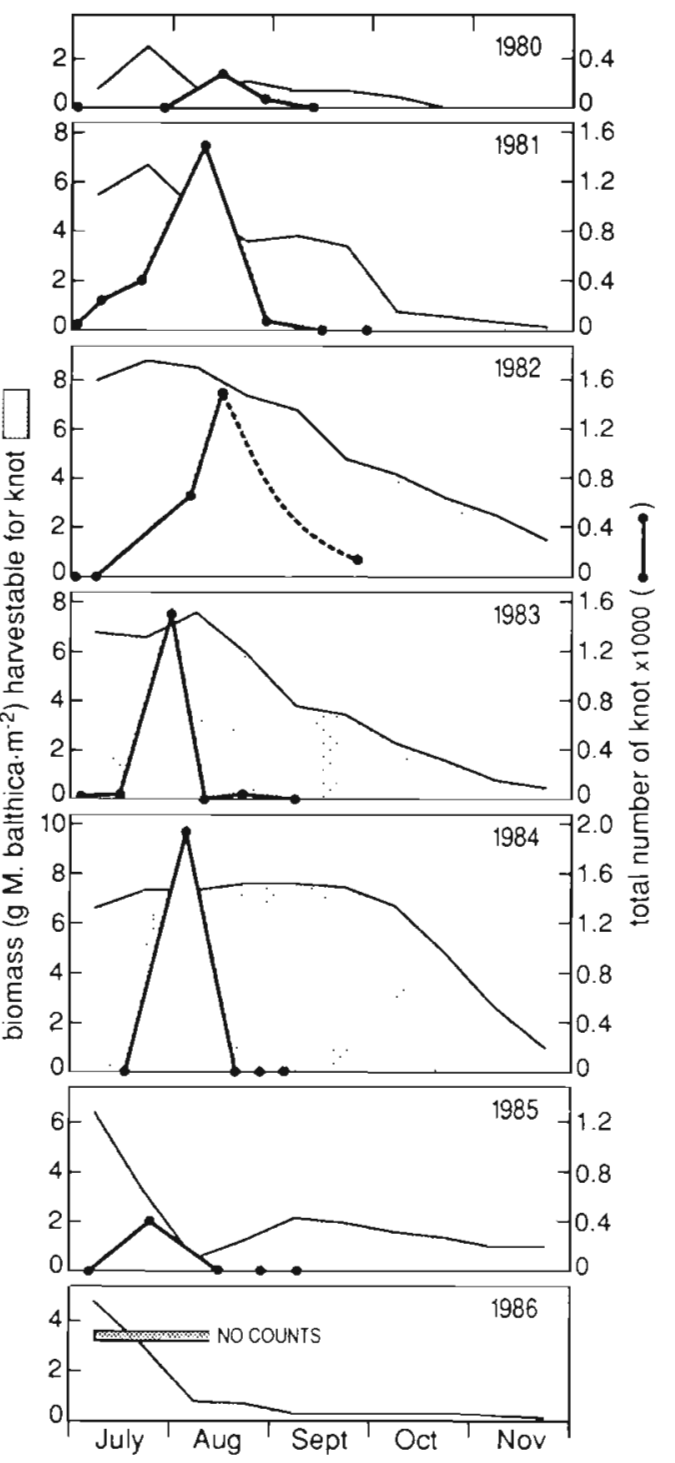

Fig. 10. Biomass of Macoma balthica (g AFDW m $\mathrm{m}^{-2}$ of individuals 6 to $16 \mathrm{~mm}$ long living in the upper $2 \mathrm{~cm}$ ) harvestable by knot Calidris canutus at Site $N$, and occurrence of knot in the study area during late summer and autumn of 1980 to 1986 
estimate intake rates over the wicle range of prey densities found in the field. The predicted intake rate is derived from 3 variables: encounter rate with prey, handling time and amount of flesh in $M$. balthica of each size class (Zwarts \& Blomert 1992), The predicted intake rate rises sharply with prey density (Fig. 11B). The 2 measurements of intake rates actually made correspond well with the predicted values (Fig. 11A), as did the intake rates of knot feeding on a variable density of $M$. balthica in semi-captive conditions (Piersma pers. comm.). Piersma (pers. comm.) found that intake rate reached a plateau of $2 \mathrm{mg} \mathrm{AFDW} \mathrm{s}^{-1}$ when $M$. balthica occurred at the extremely high biomass of more than $40 \mathrm{~g} \mathrm{AFDW} \mathrm{m}^{-2}$ Since the harvestable biomass of $M$. balthica normally varies from 0 to 10 $\mathrm{g} \mathrm{AFDW} \mathrm{m}^{-2}$, it would always be worth while for knot to search for sites with the densest food supply. From this, we conclude that choice of site must be one of the most crucial feeding decisions made by knot, because it has such a direct and large effect on intake rate.

In late summer 1981, when Macoma balthica were abundant, knot avoided sites where the biomass of hamestable $A$. balthica was less than 6 to $7 \mathrm{~g}$ AFDW $\mathrm{m}^{-2}$ (Fig. 7). This means that sites with an intake rate of

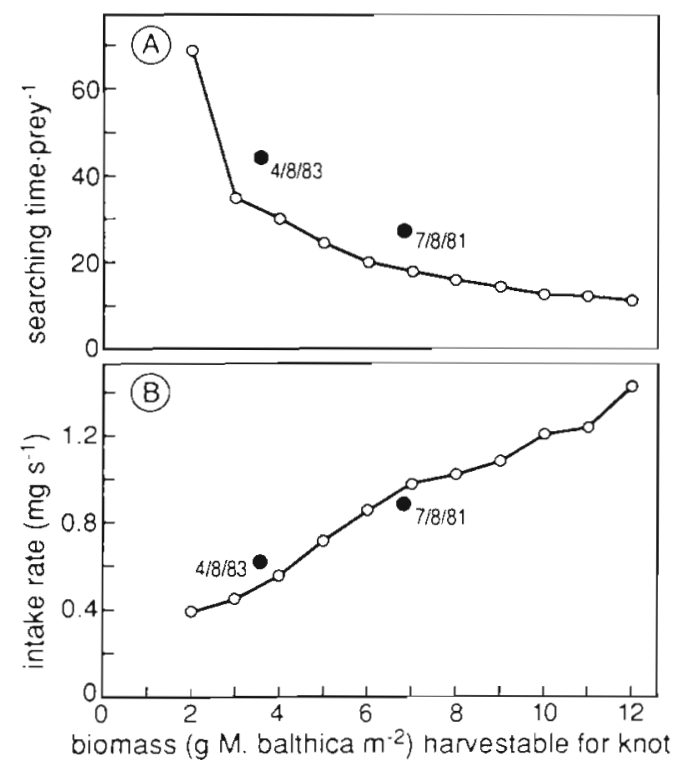

Fig. 11. Calidris canutus. (A) Searching time per prey (s) and (B) intake rate ( $m$ g AFDW s ${ }^{-1}$ ) as a function of the harvestable biomass (g AFDW m ${ }^{-2}$ of Macoma balthica 6 to $16 \mathrm{~mm}$ long living in the upper $2 \mathrm{~cm}$. The biomass data correspond to the 1981 data shown in Fig. 7. The 2 field measurements on feeding knot $(\bullet)$ were taken in August 1981 (Zwarts unpubl.) and August 1983 (Zwarts \& Blomert 1992). The line in (A) is the inverse of the encounter rate, as derived from the random touch model (Figs. 10 to 12 in Zwarts \& Blomert 1992). The line in $(\mathrm{B})$ is based on predictions derived from a model with 3 variables: handling time, encounter rate and flesh content per size class (Fig. 14 in Zwarts \& Blomert 1992) less than $0.7 \mathrm{mg} \mathrm{AFDW} \mathrm{s}{ }^{-1}$ were under-used and that the majority of knot fed on sites where they could maintain an intake rate of more than $1 \mathrm{mg} \mathrm{AFDW} \mathrm{s}^{-1}$. The following section discusses whether knot used the same decision rule to choose between feeding areas in years other than 1981, when $M$. balthica were less abundant.

\section{Response of knot to annual variation in their harvestable food supply}

Knot hardly fed in the study area in 2 years when the biomass of harvestable Macoma balthica was less than $4 \mathrm{~g} \mathrm{AFDW} \mathrm{m}^{-2}$, but did so extensively in the other 4 years, when prey were abundant (Fig. 12). However, the numbers of knot at the roost did not vary, apart from the exceptionally low number counted in 1981 (Fig. 12). Therefore, knot did not leave this part of the Wadden Sea when the harvestable food supply in the study area was very low, but instead must have found other feeding sites in the immediate vicinity. Two questuonso are therefore discussed below: (1) What decision rule is used by knot when they exploit $M$. balthica? (2) Are there years in which knot arriving in the Wadden Sea find insufficient food?

When plotted on an annual scale, knot scarcely fed on Macoma balthica when the harvestable food supply was below about $4 \mathrm{~g} \mathrm{AFDW} \mathrm{m}{ }^{-2}$ (Fig. 12), much lower than the apparent acceptance threshold in 1981 (Fig. 7).

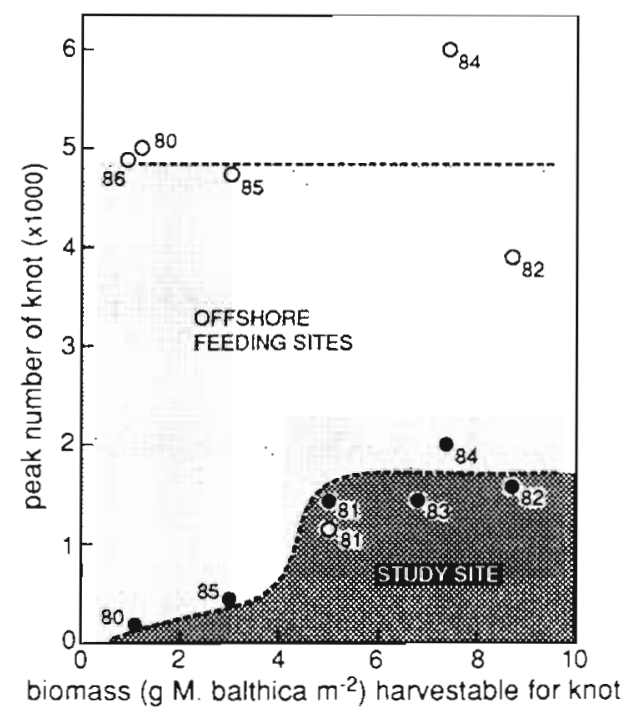

Fig. 12. Calidris canutus. Highest numbers of knot in late summer on the roost at high tide (a) and at the study site at low tide $(\bullet)$ as a function of the prey biomass harvestable by knot at the study area (g AFDW m-2 of Macoma balthica 6 to $16 \mathrm{~mm}$ long living in the upper $2 \mathrm{~cm}$ of the substrate; same data as Fig. 10). No counts were made on the roost in 1983 and at the study site in 1986 
It seems, therefore, that the acceptance threshold is not fixed, but goes down when there is not much food available. There must, however, be a lower limit below which exploitation of the food resources is not worthwhile. At thermo-neutrality, knot (119 g body weight) use about $10 \mathrm{~g}$ dry flesh (AFDW) $\mathrm{d}^{-1}$ to maintain their body weight at a constant level (Klaassen et al. 1990, Zwarts et al. 1990, Piersma pers. comm.). With the

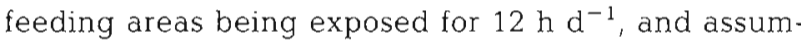
ing similar feeding rates at night as during the day, the average intake rate must be at least $0.23 \mathrm{mg} \mathrm{AFDW} \mathrm{s}^{-1}$ if the birds are to survive. Such an intake rate requires a harvestable prey density of $2 \mathrm{~g}$ AFDW of $M$. balthica $\mathrm{m}^{-2}$ (Fig. 11B). This intake rate is not sufficient, however, for knot preparing for their long-distance flight to Africa, when they have to double their daily consumption to build up their body reserves at the required rate of 3 to $4 \% \mathrm{~d}^{-1}$ (Klaassen et al. 1990). Since the feeding time cannot be increased, migrant knot must at least double their intake rate when they stay in the Wadden Sea. This implies that migrant knot would feed only at sites which provide an intake rate of at least $0.4 \mathrm{mg}$ AFDW $s^{-1}$. This further implies that the harvestable food supply of $M$. balthica would have to be at least $3 \mathrm{~g}$ AFDW m-2 (Fig. 11B), as indeed was found to be the case (Fig. 12).

In years when knot did not exploit the study site itself because the food supply was too low, the total numbers counted on the roost remained quite normal (Fig. 12). Apparently, they were able to switch to other feeding sites further offshore. In summer 1979, when there had been a heavy spatfall of Mya arenaria and Macoma balthica on the high shore (Fig. 4), the lower sandflats were completely covered by Mytilus edulis spat. This may have provided a rich food supply for knot in 1979 , but certainly did so in 1980 when the $M$. balthica in the study area were sparse. This rich food supply was not available in 1981, when all the 1979 mussels had grown past the upper size threshold of $20 \mathrm{~mm}$. Indeed no knot fed that year on the lower shore, since all the birds were concentrated on the higher mudflats in the study area (Fig. 12).

This example shows that knot may switch from one site to another, according to the prey species taken. However, even when knot feed on just one prey species, their distributions would be expected to vary from year to year. There is a very large difference between the growth rates of bivalve species, being high on the low sandflats and very low on the high mudflats. Cerastoderma edule near the low water mark may, during the first growing season, grow past the upper threshold of $12 \mathrm{~mm}$ taken by knot, while cockles at the higher shore levels may require 3 growing seasons to attain the same size (e.g. Cole 1956, Jones 1979 Sanchez-Salazar et al. 1987). In Mytilus edulis, the upper size threshold of $20 \mathrm{~mm}$ may be reached in 1 to 7 yr (e.g. Seed 1968). Similar differences in growth rates, although not as large, were found in all bivalve species on the tidal flats in the present study area (Zwarts 1988). As a consequence, knot may exploit, for instance, a particular year class of Macoma balthica on the lower shore where the larger specimens occur, but then, in subsequent years when these prey have grown too large, switch to sites where the growth rate is lower.

The largest variations in harvestable food supply over the years are primarily determined by the occurrence of severe winters and high spatfall in the following summer (Beukema 1982). Hence there are some years with high spatfall in the benthic species but many other years when reproduction is poor in all species. Thus, there is a corresponding overall pattern of recruitment in different parts of the Wadden Sea (Beukema \& Essink 1986). Fortunately for knot, various species go through the production window in different years after such a boom summer has occurred (Fig. 5), and this effect is enlarged by the locally varying growth rates. Consequently, knot may exploit, over a period of 5 or 6 yr, a food supply that came into existence during a single summer of heavy spatfall, such as occurred in 1940, 1963, 1979 and 1987 (Beukema 1976, 1982, 1989). The data collected (Fig. 10) show that there are years during which the food supply is too low for the migrant knot to be able to feed, at least on a local level. It is necessary to repeat the measurements described here on a larger scale to find out how often the food supply in the Wadden Sea is insufficient for ensuring the intake rate required by knot to build up migratory body reserves. Our prediction is that such poor years will hardly ever occur. Flocks of knot roam easily over feeding areas with a total surface of tens of $\mathrm{km}^{2}$ and it seems unlikely that good sites would not be found within such a large area, given the local variations in the food supply and the possibilities for knot to exploit different prey species (Nehls 1992). When another wader, oystercatcher Haematopus ostralegus, lost its major food supply (mussels) during a study period of 10 $y \mathrm{r}$, the species remained in the area and switched to cockles, Macoma balthica, and the ragworm Nereis diversicolor (Zwarts \& Drent 1981). No change in numbers of oystercatchers at the roost could be discerned during the episode.

\section{Knot depart before their food supply deteriorates}

There is a large difference among years in the rate of seasonal decrease in the food supply that is actually accessible to knot (Fig. 10). It might therefore be expected that the timing of migration would be delayed 
in years when Macoma balthica were scarce, yet there is little annual variation in the timing of departure (Fig. 10). The roost counts showed that knot leave the area each year around mid-August, about $3 \mathrm{wk}$ after their arrival. The migration strategy of knot is apparently to leave the Wadden Sea as soon as possible, bearing in mind that meteorological conditions must be conducive to long-distance migration. Though the abundance of the accessible food supply is rather unpredictable, there is a clear trend for the food supply to deteriorate during the course of late summer (Figs. 8 to 10). We suggest that the Siberian knot which arrive in the Wadden Sea around 1 August start building up their migration reserves immediately so that they can leave the area as quickly as possible and before the deterioration in the food supply accelerates. A study of the feeding ecology of the subspecies breeding on Greenland and in Canada, which spends the winter in the Wadden Sea and elsewhere in NW Europe (Dick et al. 1976, Roselaar 1983) accordingly would be extremely interesting: How do these knot manage to survive under conditions the Siberian knot seem to be anxious to avoid (Piersma et aì ị̂̂́ij?

Acknowledgements. We thank Jenny Cremer, Peter Esselink, Roelof Hupkes, Tjarda de Koe and Piet Zegers, with whom the bird counts were made, and Rudi van Diggelen, Lenze Hofstee, Harry Smit and the other wardens on Engelsmanplaat for counting knot there. We are grateful to Rudi Drent, John Goss-Custard and Theunis Piersma for helpful discussions and comments on the manuscript. Dick Visser carefully prepared the figures.

\section{LITERATURE CITED}

Beukema, J. J. (1976). Biomass and species richness of the macrobenthic animals living on a tidal flat area in the Dutch Wadden Sea. Neth. J. Sea Res. 10: 236-261

Beukema, J. J. (1978). Biomass and species richness of the macrobenthic animals living on a tidal flat area in the Dutch Wadden Sea: long-term changes during a period with mild winters. Neth. J. Sea Res. 12: 58-77

Beukema, J. J. (1979). Biomass and species richness of the macrobenthic animals living on a tidal flat area in the Dutch Wadden Sea: effects of a severe winter. Neth. J. Sea Res. 13: 203-223

Beukema, J. J. (1982). Annual variation in reproductive success and biomass of the major macrozoobenthic species living in a tidal flat area of the Wadden Sea. Neth. J. Sea Res. 16: $37-45$

Beukema, J. J. (1989). Long-term changes in macrozoobenthic abundance on the tidal flats of the western part of the Dutch Wadden Sea. Helgoländer Meeresunters. 43: 405-415

Beukema, J. J., Bruin, W de, Jansen, J. J. M. (1978). Biomass and species richness of the macrobenthic animals living on the tidal flats of the Dutch Wadden Sea: long-term changes during a period with mild winters. Neth J. Sea Res. 12: $58-77$

Beukema, J. J., Essink, K. (1986). Common patterns in the fluctuations of macrozoobenthic species living at different places on tidal flats in the Wadden Sea. Hydrobiologia 142: 199-207

Boere, G. C., Smit, C. J. (1981). Knot (Calidris canutus L.). In: Smit, C. J., Wolff, W J. (eds.). Birds of the Wadden Sea Balkema, Rotterdam, p. 136-145

Cole, H. A. (1956). A preliminary study of growth-rate in cockles (Cardium edule L.) in relation to commercial exploitation. J. Cons. perm. int. Explor. Mer. 22: 77-90

Desprez, M., Bachelet, G., Beukema, J J., Ducrotoy, J-P., Essink, K., Marchands, J., Michaelis, H., Robineau, B. Wilson, J. G. (1991). Dynamique des populations de Macoma balthica (L.) dans les estuaires du Nord-Ouest de l'Europe: première synthèse. In: Elliott, M., Ducrotoy, J-P. (eds.) Estuaries and coasts: spatial and temporal intercomparisons. Proc. 19th Eur. Symp. Mar. Biol. Olsen \& Olsen, Fredensborg, p. 159-165

Dick, W. J. A., Pienkowski, M. W., Waltner, M., Minton, C. D. T. (1976). Distribution and geographical origins of knot Calidris canutus in Europe and Africa. Ardea 64: 22-47

Ducrotoy, J-P., Rybarczyk, H., Souprayen, J., Bachelet, G., Beukema, J. J., Desprez, M. Dörjes, J., Essink, K., Guillou, J., Michaelis, H., Sylvand, B., Wilson, J. G., Elkaïm, B., Ibanez, F. (1991). A comparison of the population dynamics of the cockle (Cerastoderma edule, L.) in NorthWestern Europe. In: Elliott, M. Ducrotoy, J-P. (eds.) Estuaries and coasts: spatial and temporal intercomparisons. Proc. 19th Eur. Symp. Mar. Biol. Olsen \& Olsen, Fredensborg. p. 173-184

Essink, K., Beukema, J. J., Coosen, J., Craeymeersch, J. A., Ducrotoy, J-P., Michaelis, H., Robineau, B. (1991). Population dynamics of the bivalve Scrobicularia plana; comparisons in time and space. In: Elliott, M., Ducrotoy, J-P. (eds.) Estuaries and coasts: spatial and temporal intercomparisons. Proc. 19th Eur. Symp. Mar. Biol. Olsen \& Olsen, Fredensborg, p. 167-172

Gayanilo, F. C. Jr, Soriano, M., Pauly, D. (1988). A draft guide to the Compleat ELEFAN. ICLARM Software 2. International Center for Living Aquatic Resources Management. Manila

Gerritsen, A. F. G., Heezik, Y M. van, Swennen, C. (1983). Chemoreception in two further Calidris species (C. maritimus and $C$. canutus) with a comparison of the relative importance of chemoreception during foraging in Calidris species. Neth. J. Zool. 33: 485-496

Goss-Custard, J. D. (1970). Feeding dispersion in some overwintering wading birds. In: Crook, J. H. (ed.). Social behaviour in birds and mammals. Academic Press, London, p. 3-35

Jones, A. M. (1979). Structure and growth of a high-level population of Cerastoderma edule (Lamellibranchiata). J. mar. biol. Ass. U.K. 59: 277-287

Jones, N.V., Park, C. (1991). A population of Macoma balthica (L.) studied over 16 years in the Humber estuary. In: Elliott, M., Ducrotoy, J-P. (eds.) Estuaries and coasts: spatial and temporal intercomparisons. Proc. 19th Eur Symp. Mar Biol. Olsen \& Olsen, Fredensborg, p. 153-157

Klaassen, M. Kersten, M., Ens, B. J. (1990). Energetic requirement for maintenance and premigratory body mass of waders wintering in Africa. Ardea 78: 209-220

NehIs, G. (1992). Food selection of knots Calidris canutus in the Wadden Sea: the importance of seasonal and annual variation of food avaılability. Wader Study Group Bull. (in press)

Obert, B., Michaelis, H. (1991). History and ecology of the mussel beds (Mytilus edulis L.) in the catchment area of a Wadden Sea tidal inlet. In. Elliott, M., Ducrotoy, J-P. (eds.) 
Estuaries and coasts: spatial and temporal intercomparisons. Proc. 19th Eur. Symp. Mar Biol. Olsen \& Olsen, Fredensborg, p. 185-194

Piersma, T (1987). Production by intertidal benthic animals and limits to their predation by shorebirds: a heuristic model. Mar. Ecol. Prog. Ser. 38: 187-196

Piersma, T., Drent, R., Wiersma, P. (1991). Temperate versus tropical wintering in the world's nothernmost breeder, the knot: metabolic scope and resource levels restrict subspecies options. Acta XX Congressus Internationalis Ornithologici, Christchurch, p. 761-772

Piersma, T., Zwarts, L., Bruggemann, J. H. (1990). Behavioural aspects of the departure of waders before long-flight distances: flocking, vocalizations, flight paths and diurnal timing. Ardea 78: 157-184

Roselaar, C. S. (1983). Subspecies recognition in knot Calidris canutus and occurrence of races in western Europe. Beaufortia 33: 97-109

Sanchez-Salazar, M. E., Griffiths, C. L., Seed, R. (1987). The interactive roles of predation and tidal elevation in structuring populations of edible cockles Cerastoderma edule. Estuar. coast. Shelf Sci. 25: 245-260

Seed, R. (1968). Factors influencing shell shape in the mussel Mytilus edulis. J. mar. biol. Ass. U.K. 48: 561-584

Zwarts, L. (1988). De bodemfauna van de Fries-Groningse

This article was submitted to the editor waddenkust. Flevobericht 194. Rijksdienst voor de IJsselmeerpolders, Lelystad

Zwarts, L. (1991). Seasonal variation in body condition of the bivalves Macoma balthica, Scrobicularia plana, Mya arenaria and Cerastoderma edule in the Dutch Wadden Sea. Neth. J. Sea Res. 28: 231-245

Zwarts, L., Blomert, A.-M. (1992). Why knot Calidris canutus take medium-sized Macoma balthica when six prey species are available. Mar. Ecol. Prog. Ser. 83: 113-128

Zwarts, L., Blomert, A.-M., Ens, B. J., Hupkes, R., van Spanje, T M. (1990). Why do waders reach high feeding densities on the intertidal flats of the Banc d'Arguin, Mauritania? Ardea 78: 39-52

Zwarts, L., Drent, R. H. (1981). Prey depletion and the regulation of predator density: oystercatchers (Haematopus ostralegus) feeding on mussels (Mytilus edulis). In: Jones, N. V., Wolff, W. J. (eds.) Feeding and survival strategies of estuarine organisms. Plenum Press, New York, p. 193-216

Zwarts, L., Wanink, J. (1984). How oystercatchers and curlews successively deplete clams. In: Evans, P. R., Goss-Custard, J. D., Hale, W. G. (eds.) Coastal waders and wildfowl in winter. Cambridge University Press, Cambridge, p. 69-83

Zwarts, L., Wanink, J. (1989). Siphon size and burying depth in deposit- and suspension-feeding benthic bivalves. Mar. Biol. 100: 227-24

Manuscript first received: October 14, 1991

Revised version accepted: April 24, 1992 